\title{
Eco-physiological and biochemical study of two of the most contrasting forms of Chondrus crispus (Rhodophyta, Gigartinales)
}

\author{
Thierry Chopin ${ }^{1}$, Jean-Yves Floc' ${ }^{2}$ \\ ${ }^{\prime}$ Marine and Estuarine Research Group, Division of Sciences, University of New Brunswick, Po Box 5050, Saint John, New \\ Brunswick, Canada E2L 4L5 \\ ${ }^{2}$ Laboratoire de Physiologie Végétale, Faculté des Sciences, Université de Bretagne Occidentale, 6 Avenue V. Le Gorgeu, \\ F-29287 Brest Cedex, France
}

\begin{abstract}
Seasonal variations of distribution of the gametophytic and tetrasporophytic generations, growth, carrageenans, phosphorus and nitrogen nutrition, and dry matter content were studied in 2 of the most contrasting forms of the red alga Chondrus crispus Stackhouse in Britanny, France. Seasonal variations of generations were more pronounced in the infralittoral than in the midlittoral form; the former had more reproductively mature plants and twice as many tetrasporophytes. Growth was greater in the infralittoral than in the midlittoral form. Contents of total carrageenans were comparable in the 2 forms; the $\mathrm{K}^{-}, \mathrm{t} \mathbf{\mathrm { l }}$, and $\mu$-carrageenan structures did not vary significantly (qualitatively, quantitatively, during the year, or between the 2 forms). The midlittoral form had a higher total phosphorus content, more marked seasonal variations and an earlier spring decline than the infralittoral form. Seasonal variations of total nitrogen content had different patterns in the 2 forms during summer The dry matter content of the infralittoral form was lower than that of the midlittoral form. These eco-physiological and biochemical differences and similarities are discussed in terms of the polymorphism of this alga.
\end{abstract}

\section{INTRODUCTION}

The extreme morphological plasticity of the red alga Chondrus crispus Stackhouse was recognized almost 2 centuries ago as attested by the denominations Fucus polymorphus Lamouroux (1805) and Polymorpha Stackhouse (1809). Different authors have proposed a wide range in the number of varieties, from 2 (Harvey 1846-1851) to 35 (Lamouroux 1813), and the status of the polymorphism of this alga still puzzles phycologists.

Many authors deemed morphological and coloration variations to be attributable to different ecological parameters: wave exposure and currents (Lilly 1968). salinity (Mathieson \& Burns 1975), depth (Prince 1971), light intensity (MacFarlane 1956), and quantity of available nutrients in seawater (Neish \& Fox 1971). Thomas (1938) and Newton et al. (1957) suggested that polymorphism was a multifactorial phenomenon resulting from several interacting environmental factors. The latter authors considered that some of the so-called varieties were different stages in development of the same plant and thus concluded that none of these forms were real varieties. MacFarlane (1968) used the term 'ecological types'. The transition betweeen infralittoral forms and those of the upper part of the midlittoral zone has, however, not been clearly established. Between these extreme forms a whole series of intermediate forms exist which, moreover, can be observed within a few centimeters of each other in the same population. Therefore, environmental pressure alone cannot explain entirely the morphological heterogeneity of Chondrus crispus.

Genetic variability has been proposed by several authors. To this end, different kinds of experiments have been carried out: transplants (Floc'h 1969), chromosome analyses (Hanic 1973), growth of medullary tissues (Chen \& Taylor 1978), structural and anatomical studies and hybridization trials (Chen \& Taylor 1980a, b, Guiry 1991). None of them, however, allowed an unambiguous conclusion on the level of speciation of the different forms.

Over several years of investigations, encompassing the seasonal variations of distribution of the different generations of the life cycle, growth, carrageenan content, phosphorus and nitrogen nutrition, and dry matter content, a number of differences and similarities 
between 2 of the most contrasting forms of Chondrus crispus have been observed and are reported in the present paper as an eco-physiological and biochemical contribution towards solving the polymorphism enigma of this alga.

\section{MATERIALS AND METHODS}

Materials. Algae were collected from Porz Liogan Cove in Brittany near Brest, France (Chopin \& Floc'h 1987 ) at 2 different shore levels to allow all experiments to be conducted in parallel on two of the most contrast ing forms of Chondrus crispus according to the Harvey (1846-1851) definition (Fig. 1).

The first form has its maximum of population density at a high level of the midlittoral zone, among Ascophyllum nodosum, and was therefore called the 'midlittoral' form. It is a large, thin, and membranous plant, with round tips, similar to the variety typica Turner described by Newton et al. (1957). The second form has its maximum of population density at very low tide among Laminariales and was consequently called 'infralittoral'. It is a narrow, subcylindrical, and cartilaginous plant, with sharp tips, resembling the variety aequalis Turner.

Gametophyte/sporophyte distribution. Approximately $3 \mathrm{~kg}$ fresh weight (FW) of plants of each form were collected monthly, between November 1982 and November 1983. In the laboratory, plants were sorted into 3 categories according to the presence or absence of cystocarps and sori on the surface of the fronds: (1) mature female gametophytes, (2) mature tetrasporophytes, and (3) immature plants (which, on occasion, included mature male gametophytes not detectable with the naked eye). Each set was washed with seawater, and epiphytes and epizoans were removed.

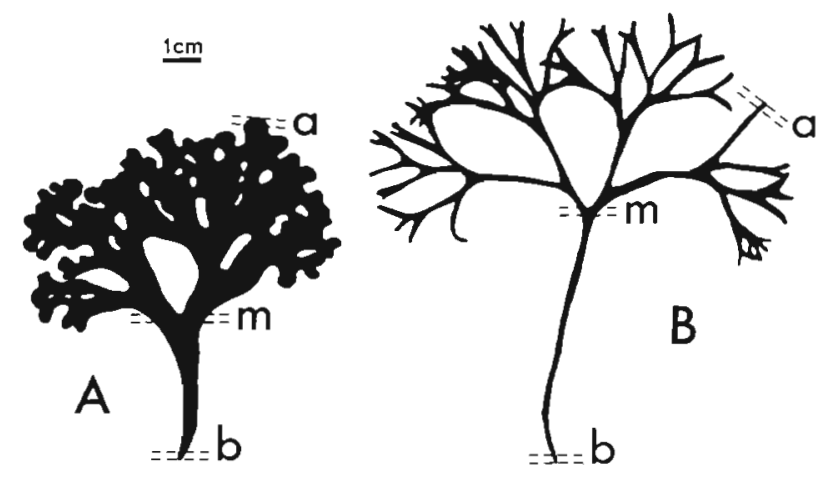

Fig. 1. Chondrus crispus. Two contrasting forms: (A) midlittoral form and $(B)$ infralittoral form. Location of sections at 3 different parts of the thallus: apex (a), middle (m), and base (b)
Clean algae were then dried at $60^{\circ} \mathrm{C}$ until constant dry weight was reached (minimum of $72 \mathrm{~h}$ ). Each set was weighed and results were expressed in percentages of the total collection for each form and each month.

Measurement of growth by fluorescence labelling. To work with homogeneous material, this study, and the following experiments, were all performed on plants with 4 or more dichotomies and a frond length between 6 and $10 \mathrm{~cm}$, corresponding to plants of Classes 3 and 4 in the classification system of Chopin et al. (1988). A fluorescent and vital stain, called Cellufluor (equivalent of Calcofluor White M2R), was used to localize and measure growth, from April 1984 to April 1985 , based on the principle that newly-formed rows of cortical cells develop a dark area while cortical cells present at the time of the labelling pulse are still fluorescent. Labelling procedure in the field and transmission fluorescence microscopy observation in the laboratory have been described previously (Chopin \& Floc'h 1987).

Extraction and content of total carrageenans. Samples of female gametophytes collected from November 1982 to November 1983 were extracted as described in Chopin et al. (1987). After centrifugation, the supernatant was precipitated in 2 volumes of ethanol. The coagulum was collected by filtration with a $34 \mu \mathrm{m}$ Nytrel-TI filtration netting, dried for $24 \mathrm{~h}$ at $60^{\circ} \mathrm{C}$, weighed, and milled with a Dangoumau grinder. Second and third extractions were processed from the pellets of first and second extractions, respectively, and each time precipitates and coagula were collected in the same manner

Infrared and ${ }^{13} \mathrm{C}$-NMR carrageenan analysis. IR spectra from first, second, and third extraction samples were recorded with a Pye Unicam SP 2000 spectrometer. Sample films were prepared by evaporating $0.24 \%$ carrageenan solutions on PVC plates.

Proton-composite pulse decoupled ${ }^{13} \mathrm{C}$-NMR spectra of total extracts were recorded on a Bruker WM 400 spectrometer $\left(100.57 \mathrm{MHz}\right.$ ) in $\mathrm{D}_{2} \mathrm{O}$ solution (20 $\mathrm{mg}$ $\mathrm{ml}^{-1}$ ) at $80^{\circ} \mathrm{C}$. A spectral width of $12.5 \mathrm{kHz}$ was used with a pulse angle of $65^{\circ}(12 \mu \mathrm{s})$ and a repetition time of $0.655 \mathrm{~s}$. Spectra of $16 \mathrm{~K}$ data points were accumulated. Chemical shifts (ppm) were measured relative to internal dimethylsulfoxide (DMSO, $39.6 \mathrm{ppm}$ ) and are reported as values downfield from external tetramethylsilane (TMS). Percentages of different carrageenan structures were calculated by integration of anomeric-carbon-atom peaks (Bellion et al. 1983, Usov 1984).

Determination of total $P$ and total $N$ content in the thallus. After drying at $105^{\circ} \mathrm{C}$ to constant dry weight and acidic mineralization $\left(\mathrm{H}_{2} \mathrm{SO}_{4}+\mathrm{HNO}_{3}\right)$, total $\mathrm{P}$ was measured monthly, between October 1982 and November 1983, by the method of Charlot (1966) on 
parts, taken at 3 different locations (apex, middle, and base; Fig. 1), of approximately 60 thalli. Results from the 3 parts were then averaged to obtain data for the whole thallus. These samples were also used to determine the dry weight content, expressed in percentage of fresh weight.

Total $\mathrm{N}$ was measured on disks (total $250 \mathrm{mg}$ FW) taken from approximately 25 thalli for each experiment, between November 1983 and August 1984. After extraction according to Hourmant et al. (1979), centrifugation, and mineralization $\left(\mathrm{H}_{2} \mathrm{SO}_{4}+\mathrm{H}_{2} \mathrm{O}_{2}\right)$, aliquots of the residue of the insoluble fraction pellet were distilled with a Parnas and Wagner apparatus and titrated with a sulfuric acid solution.

For all the studied parameters, comparison of the 2 forms was statistically tested with 2 nonparametric tests, the Kruskall-Wallis and the Mann-Whitney tests. Differences where $p<0.1$ were taken as significant.

\section{RESULTS}

\section{Distribution of mature female gametophytes and tetrasporophytes}

Mature female gametophytes and tetrasporophytes represented, at some times of the year, very low percentages of the population; however they never disappeared totally (Fig. 2). Occurrence of mature female gametophytes was maximal during summer in the

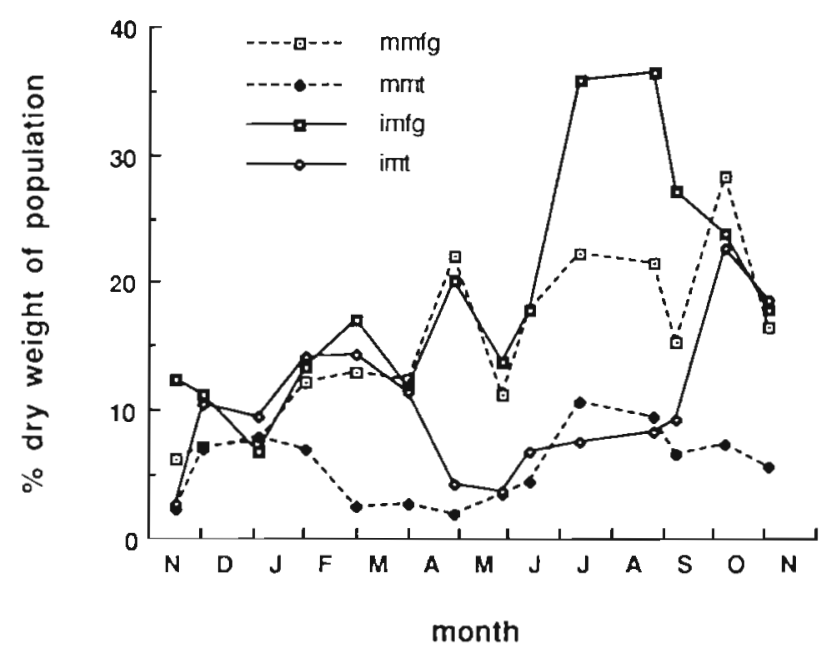

Fig. 2. Chondrus crispus. Seasonal variations of mature female gametophytes and mature tetrasporophytes in the midlittoral and infralittoral forms. Results are expressed in \% dry weight of the population. mmfg: midlittoral mature female gametophytes; mmt: midlittoral mature tetrasporophytes; imfg: infralittoral mature female gametophytes; imt: infralittoral mature tetrasporophytes infralittoral form and during summer/beginning of fall in the midlittoral one. For both forms it was minimal during winter. The distribution of the mature tetrasporophytes showed 2 peaks per year; they were recorded earlier (beginning of winter, summer) in the midlittoral than in the infralittoral form (winter, beginning of fall). Minima were observed in the middle of autumn and during spring.

Percentage variations were more pronounced in the infralittoral form, which contained more reproductive plants than the midlittoral form. The percentages of mature female gametophytes were always higher than those of mature tetrasporophytes except at the beginning of winter in both forms, and also in the middle of fall in the infralittoral form. When all the monthly collections were pooled, mature female gametophytes represented $18.9 \%$ and $15.2 \%$ of the infra- and midlittoral populations, respectively, whereas mature tetrasporophytes represented only $10.3 \%$ and $5.6 \%$. The latter numbers also showed that there were almost twice as many mature tetrasporophytes in the infralittoral than in the midlittoral zone.

\section{Variations of growth}

As in both forms apical tissues were always actively growing regions (no fluorescence of the cell walls of the cortical cells) and no growth occurred at the level of the basal tissues (all cell walls of the cortical cells still labelled 1 mo after staining), tissues from the middle of the thallus were used to analyze the differences in growth pattern between the 2 forms. Counting the number of nonfluorescent cortical cell rows in transverse sections (Fig. 3) showed that growth was greater in the infralittoral form, except in November and April where it was similar in both forms. No growth was recorded for the whole winter in the midlittoral form, whereas there was still a slight growth during December in the infralittoral form. The measurement of the length of nonfluorescent tissue at the apex on longitudinal sections (Fig. 4) confirmed that growth of the infralittoral form was greater than or equal to that of the midlittoral form.

\section{Carrageenan analyses}

All IR spectra (Fig. 5) were characteristic of a dominant $\kappa$-carrageenan structure with a smaller amount of $\iota$ carrageenan (peaks at $1240,930,845$, and $805 \mathrm{~cm}^{-1}$; Stancioff \& Stanley 1969). No precursors ( $\mu$ - or $v$-carrageenans) could be detected by IR spectrometry. Spectra of the 2 forms were similar. When comparing spectra of first, second and third extractions, one can 

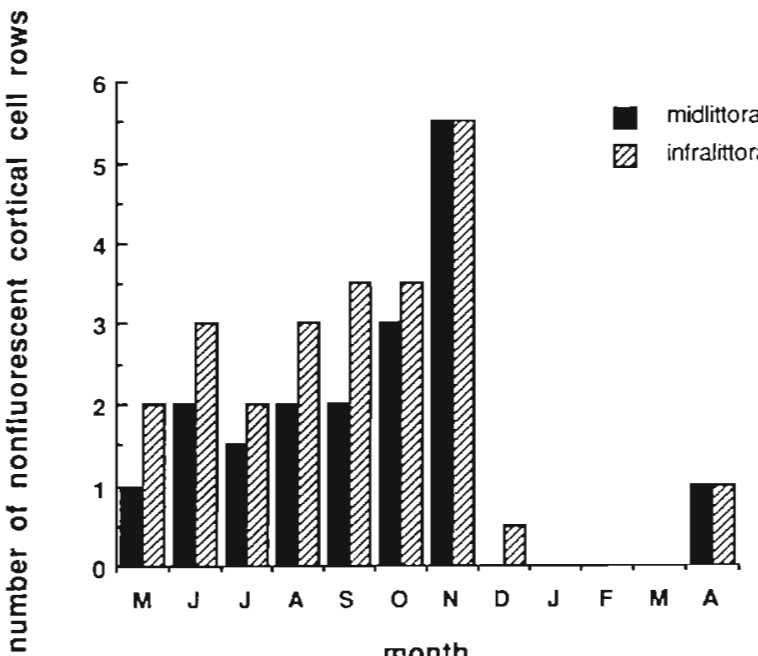

Fig. 3. Chondrus crispus. Seasonal variations of growth at the middle of the thallus in the midlittoral and infralittoral forms. Results are expressed in number of nonfluorescent cortical cell rows in transverse sections

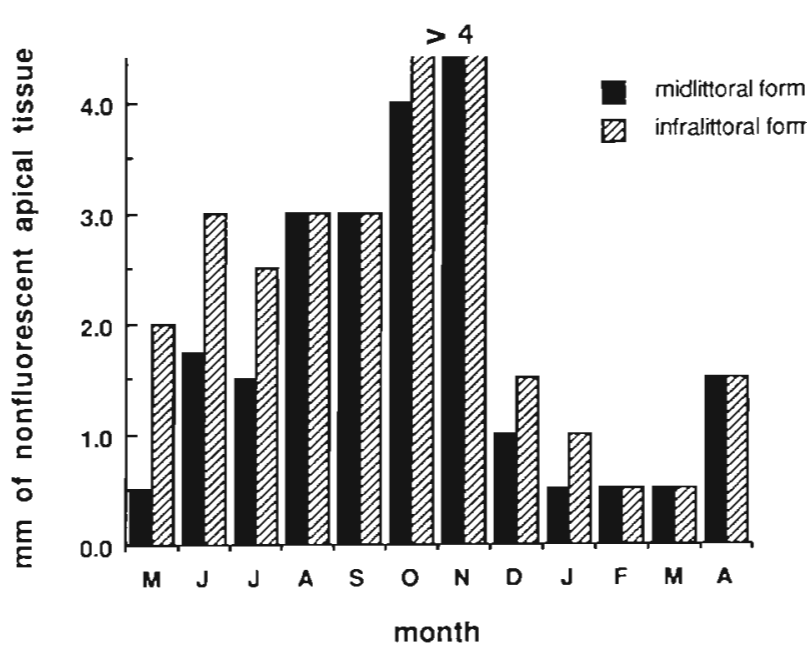

Fig. 4. Chondrus crispus. Seasonal variations of growth at the tip of the thallus in the midlittoral and infralittoral forms. Results are expressed in $\mathrm{mm}$ nonfluorescent apical tissue in longitudinal sections

notice a general decrease in peak resolution as extractions progressed, and, in particular, the peak at 970 $\mathrm{cm}^{-1}$, present in the first extraction, became a shoulder in the second, and completely disappeared in the third. The peak at $805 \mathrm{~cm}^{-1}$ (characteristic of the istructure) slightly increased in the second and third extractions of the midlittoral form.

The study of the seasonal variations of total carrageenan content has been published previously (Cho-
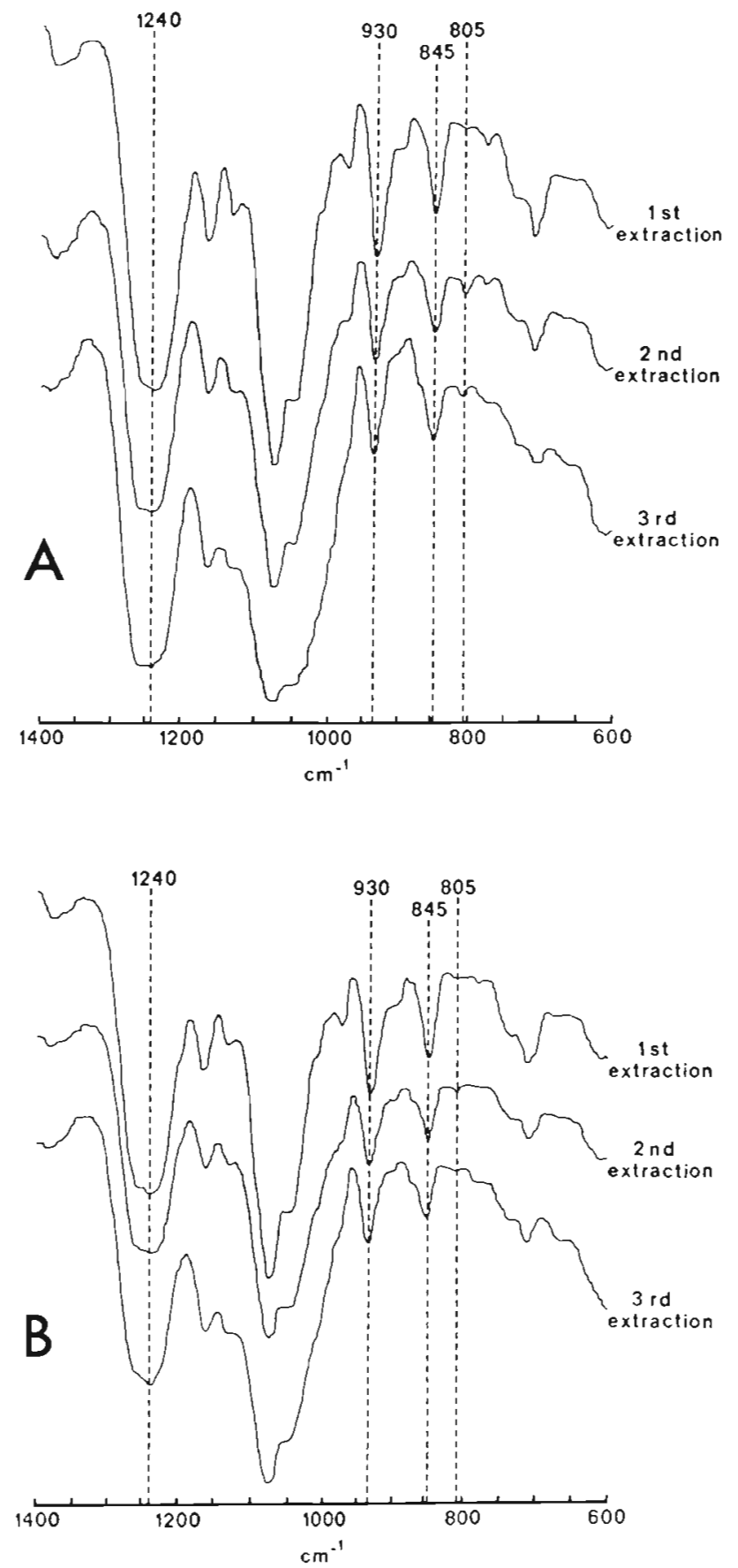

Fig. 5. Chondrus crispus. Dispersive IR spectra of the carrageenans extracted from female gametophytes of $(A)$ the midititoral form (1st extraction, $96.3 \%$ of total extraction; 2 nd extraction, $3.6 \%$; 3 rd extraction, $0.1 \%$ ) and (B) the infralittoral form (1st extraction, $93.6 \%$; 2nd extraction, $6.2 \%$; 3 d extraction, $0.2 \%$ ) of Chondrus crispus collected on November 3,1983

pin et al. 1987): the pattern was similar in the 2 forms and vertical distribution had no significant influence on carrageenan content (Table 1). Only the periods of 
Table 1. Chondrus crispus. Extreme contents of total carrageenans extracted from female gametophytes in the midlittoral and infralittoral forms. Results are expressed in \% dry wt. Percentages in brackets indicate differences between maximal and minimal carrageenan contents

\begin{tabular}{|c|c|c|c|}
\hline & \multicolumn{2}{|c|}{ Midlittoral form } & Infralittoral form \\
\hline Maximal content & \multicolumn{2}{|c|}{49.9 (November) } & 48.4 (November) \\
\hline Minimal content & 37.9 (May) & 37.4 (August) & 35.9 (March) \\
\hline Difference & $12.0(24.0 \%)$ & $12.5(25.0 \%)$ & $12.5(25.8 \%)$ \\
\hline
\end{tabular}

lowest content were different: March for the infralittoral form, and May and August for the midlittoral form.

IR spectra of the 3 extractions for each form were obtained monthly in the aim of studying potential qualitative and quantitative seasonal variations of the different structures of carrageenans in the total extracts. The peak ratios $930 / 845$ and $1240 / 845$ were calculated; however, due to the lack of precision of this spectrometric method and the difficulty in defining the base-line for the different spectra, no conclusion could be reached. ${ }^{13} \mathrm{C}$-NMR spectrometry was then used.

All ${ }^{13} \mathrm{C}$-NMR spectra (Fig. 6) showed 12 major peaks with chemical shifts characteristic of the $\mathrm{k}$-carrageenan structure, which is dominant in all extracts. The $\mathbf{l -}$ carrageenan structure, in lesser quantity, was also detected by the presence of the peaks $\mathrm{Ia}_{1}(91.7 \mathrm{ppm})$ and $\operatorname{Ig}_{4}(71.8 \mathrm{ppm})$. The signals $X(104.5 \mathrm{ppm})$ and $Y^{\prime}$ (97.5 ppm) indicated the presence of the precursor $\mu$ carrageenan structure.

The seasonal study of carrageenan structures was conducted on total extracts of plants of both forms collected in February, May, and August. Spectrum comparison (Fig. 6) did not show any qualitative variations of the different carrageenan structures according either to seasons or forms. One can, however, notice the occurrence of several signals in the region of the $\operatorname{Ig}_{4}$ peak, in the 2 forms, especially in February and, to a lesser extent, in August. The significance of the presence of these signals remains unknown as they are presently unassigned. The methods of obtaining the spectra allowed the calculation of the relative composition in $\mathrm{K}^{-}, \mathrm{l-}$, and $\mu$-carrageenan structures of the extracts by integration of the peaks corresponding to the signals $\mathrm{Ia}_{1}(91.7 \mathrm{ppm}), \mathrm{Ka}_{1}(95.0 \mathrm{ppm})$, and $\mathrm{Y}^{\prime}(97.5$ ppm). Table 2 showed no marked quantitative seasonal variations of the different carrageenan structures. Moreover, the slightly higher content in $\mathrm{k}$-carrageenan (72\%) and lower content in $\mu$-carrageenan $(5 \%)$ of the midlittoral form compared to the infralittoral form (68\% and $8 \%$, respectively) represented variations at the limit of the detection threshold of the ${ }^{13} \mathrm{C}-\mathrm{NMR}$ spectrometry. It is, therefore, better to conclude that there was no significant difference between the 2 forms, which had an average dominant $\mathrm{k}$-carrageenan feature $(70 \%)$ with less l-carrageenan (23\%) and a small amount of $\mu$-carrageenan $(7 \%)$.

\section{Variations of total $\mathbf{P}$ and total $\mathbf{N}$ contents}

Data on seasonal variations of total $\mathrm{P}$ content for the whole thallus have been published previously (Chopin et al. 1990b). They showed that the total P content was always higher in the midlittoral than in the infralittoral form, except at the end of May when the 2 forms had similar contents. Moreover, the drop in total P content during spring and summer was in 3 steps in the midlittoral form (abrupt drop starting at the end of April, levelling off until mid-July, and abrupt drop again to the lowest value at the end of August), whereas it started 1 mo later (end of May) and was progressive

Table 2. Chondrus crispus. $k-, \mathrm{l}-$, and $\mu$-carrageenan contents of total extracts from female gametophytes in the midlittoral and infralittoral forms. Results are expressed in \% of total extracts

\begin{tabular}{|c|c|c|c|c|c|c|}
\hline \multirow[t]{2}{*}{ Structure } & \multirow[t]{2}{*}{ Form } & \multicolumn{3}{|c|}{ Month } & \multicolumn{2}{|c|}{ Average } \\
\hline & & February & May & August & & \\
\hline K & $\begin{array}{l}\text { Midlittoral } \\
\text { Infralittoral }\end{array}$ & $\begin{array}{l}71 \\
68\end{array}$ & $\begin{array}{l}70 \\
66\end{array}$ & $\begin{array}{l}73 \\
69\end{array}$ & $\begin{array}{l}72 \\
68\end{array}$ & 70 \\
\hline$\imath$ & $\begin{array}{l}\text { Midlittoral } \\
\text { Infralittoral }\end{array}$ & $\begin{array}{l}23 \\
25\end{array}$ & $\begin{array}{l}25 \\
24\end{array}$ & $\begin{array}{l}22 \\
22\end{array}$ & $\begin{array}{l}23 \\
24\end{array}$ & 23 \\
\hline$\mu$ & $\begin{array}{l}\text { Midlittoral } \\
\text { Infralittoral }\end{array}$ & $\begin{array}{l}6 \\
7\end{array}$ & $\begin{array}{r}5 \\
10\end{array}$ & $\begin{array}{l}5 \\
9\end{array}$ & $\begin{array}{l}5 \\
8\end{array}$ & 7 \\
\hline
\end{tabular}



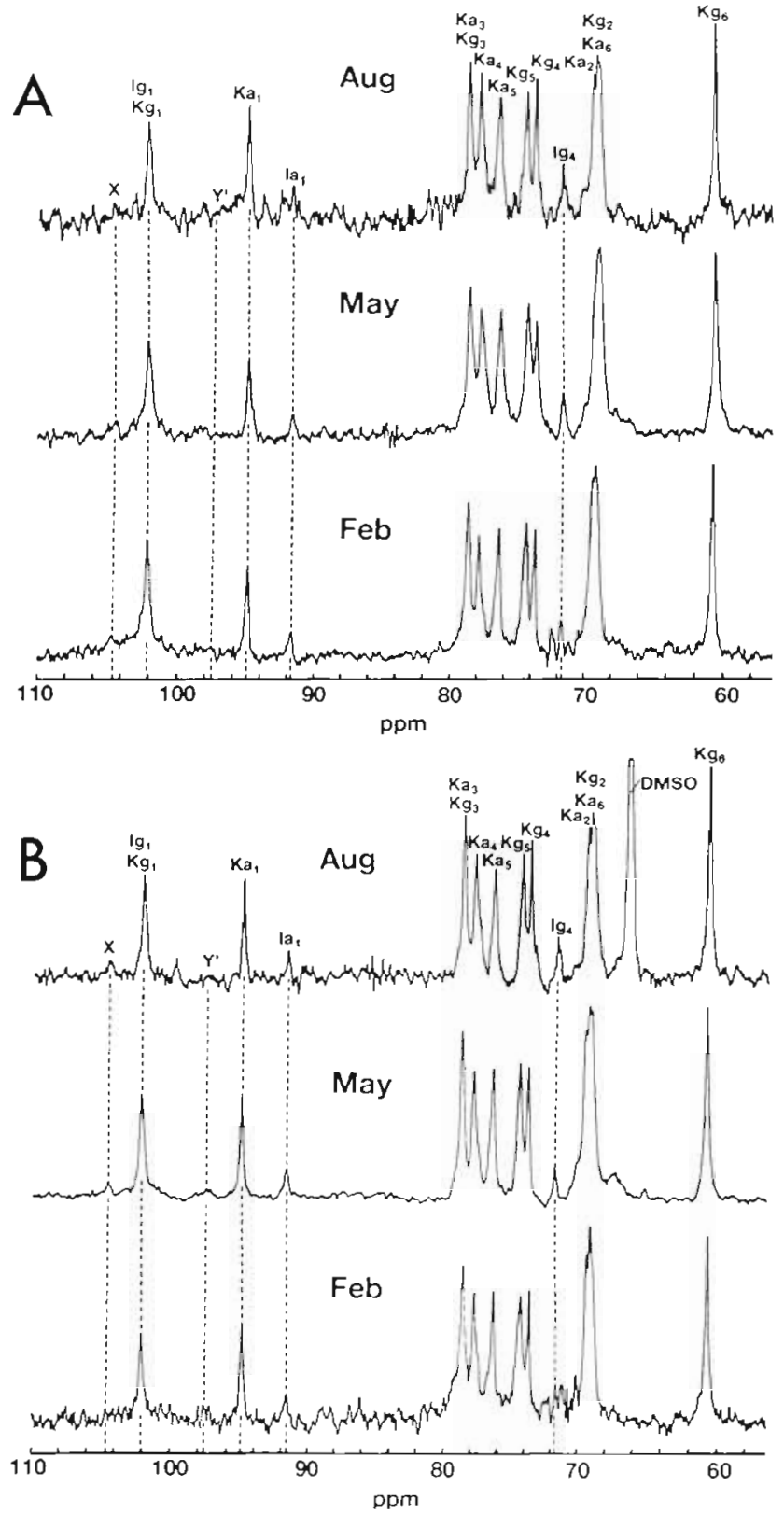

Fig. 6. Chondrus crispus. ${ }^{13} \mathrm{C}-\mathrm{NMR}$ spectra of the carrageenans extracted from female gametophytes of (A) the midlittoral form (February 1983, 83000 scans; May, 25000 scans; August, 45000 scans) and (B) the infralittoral form (February, 20000 scans; May, 77000 scans; August, 74000 scans). Chemical shifts (ppm), measured relative to TMS, are assigned to carbon atoms of the repeating disaccharide of $\mathrm{k}$ and 1 -carrageenans $(g=1,3$-linked $\beta$-D-galactose-4-sulfate; $\mathrm{a}=1,4$-linked 3,6-anhydro- $\alpha$-D-galactose or 1,4 linked 3,6anhydro- $\alpha$-D-galactose-2-sulfate). $X$ and $Y$ refer to the anomeric carbon atoms of 1,3-linked $\beta$-D-galactose-4-sulfate and 1,4-linked $\alpha$-D-galactose-6-sulfate, respectively, of $\mu$-carrageenan

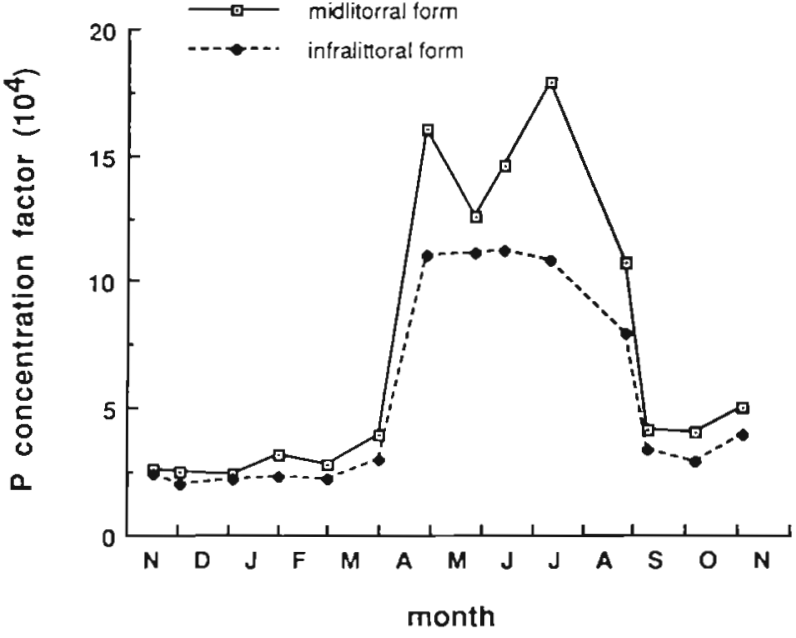

Fig. 7 Chondrus crispus. Seasonal variations of the P concentration factor in the midlittoral and infralittoral forms

through the end of August in the infralittoral form. The total $\mathrm{P}$ content varied from 1.9 to $3.3 \mathrm{mg} \mathrm{P} \mathrm{g}^{-1}$ (dry wt) in the midlittoral form and from 1.5 to $2.5 \mathrm{mg} \mathrm{P} \mathrm{g}^{-1}$ (dry wt) in the infralittoral form. The calculation of the concentration factor, between the total P content in the thallus and the mineral $\mathrm{P}$ content in seawater (Chopin et al. 1990b), and the pattern of its seasonal variations (Fig. 7) showed that it was similar in the 2 forms from the end of summer to the beginning of spring but different during the second part of the spring and most of the summer. It was always higher in the midlittoral form (between $2.4 \times 10^{4}$ and $17.9 \times 10^{4}$ ) than in the infralittoral form (between $2.0 \times 10^{4}$ and $11.2 \times 10^{4}$ ).

Total $\mathrm{N}$ content was high in November and dropped significantly until June in both forms (Fig. 8). From June to August, the 2 forms evolved differently: the total $N$ content increased to the level recorded in March in the midlittoral form, whereas it continued to decrease in the infralittoral one.

\section{Variations of the dry matter content}

The seasonal pattern of the dry matter was comparable in the 2 forms (Fig. 9). The infralittoral form, however, had a statistically significantly lower dry matter content than the midlittoral form, and did not show as marked winter and summer maxima.

\section{DISCUSSION}

Comparison of studies on the distribution of the different generations in the isomorphic alga Chondrus crispus 


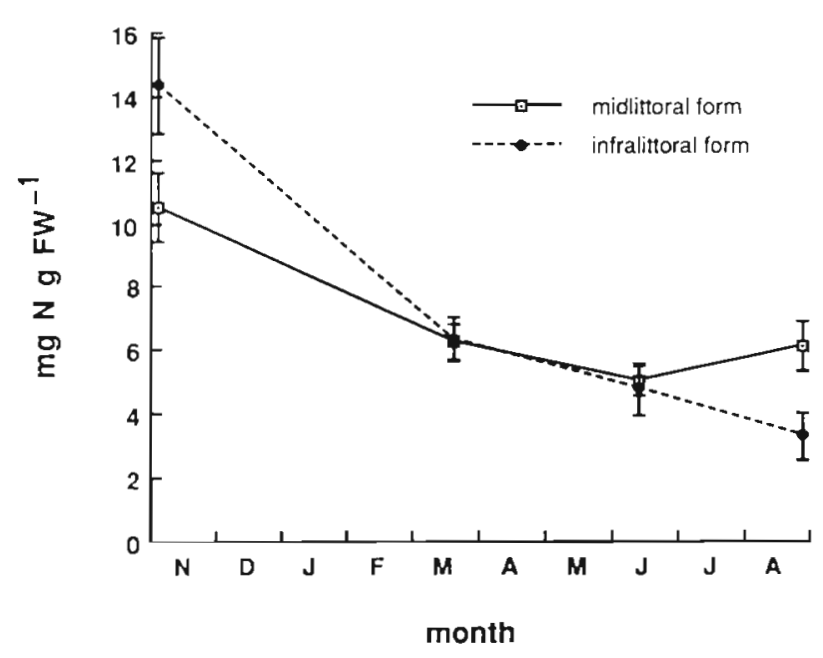

Fig. 8. Chondrus crispus. Seasonal variations of total N content in the midlittoral and infralittoral forms. Results are expressed in $\mathrm{mg} \mathrm{N} \mathrm{g}^{-1}$ fresh wt. Means \pm standard deviation $(\mathrm{n}=3$ )

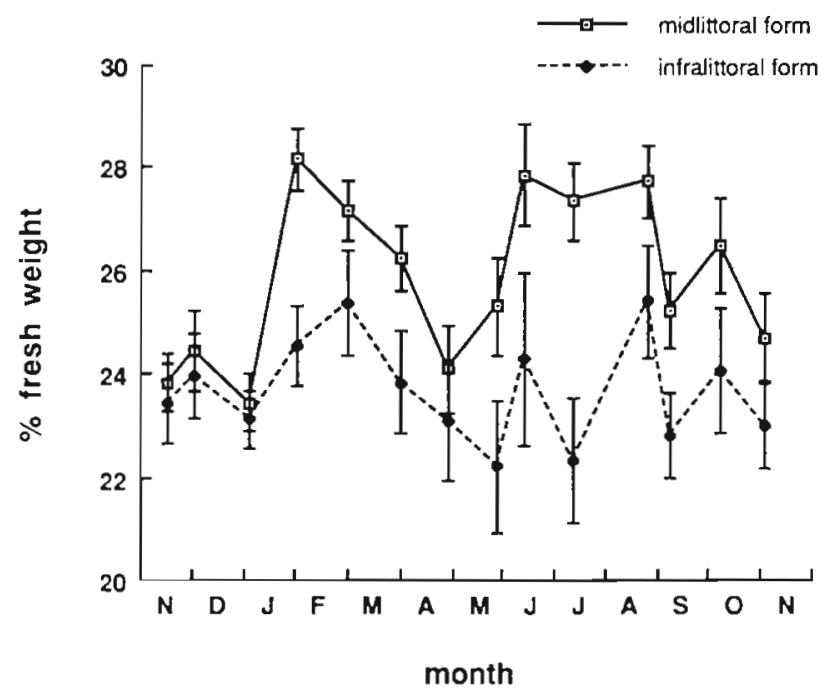

Fig. 9. Chondrus crispus. Seasonal variations of dry matter content in the midlittoral and infralittoral forms. Results are expressed in \% fresh weight. Means \pm standard deviation $(\mathrm{n}=5)$

is difficult as some take into consideration only mature plants (most studies, including ours) and others consider both vegetative and mature plants and differentiate gametophytes and tetrasporophytes on the basis of the type of carrageenans they contain (resorcinol test of Craigie \& Leigh 1978). At Porz Liogan, the unimodal distribution of gametophytes, and bimodal distribution of tetrasporophytes, were similar to those observed in many locations (Chopin 1986). The reverse type of distribution (bimodal for gametophytes and unimodal for tetrasporophytes) has, however, been reported in Spain (Fernandez \& Menendez 1991), and bimodal distribution for both generations has been shown in Canada (Chopin et al. 1988). These changes in mode of distribution and in the ratio gametophytes/tetrasporophytes have been attributed, so far, to wave exposure, depth, differential reproductive capacity, harvesting pressure, and substratum disturbance (Prince \& Kingsbury 1973, Mathieson \& Burns 1975, Craigie \& Pringle 1978, Bhattacharya 1985, Chopin et al. 1988, Lazo et al. 1989); however further investigations, especially over a longer period of time, are needed to check if other parameters could be responsible.

In the infralittoral form, the summer maximum of the gametophytes was between the 2 tetrasporophyte maxima (winter, beginning of fall) which could be explained by the alternation of generations in the life cycle of this species. This pattern was, however, not observed in the midlittoral form in which both generations were significantly represented during summer. Contrary to what Tveter-Gallagher et al. (1980) observed in New Hampshire, USA, the seasonal variations of the 2 generations at Porz Liogan were less marked in the midlittoral than in the infralittoral form. This could be explained by the fact that environmental conditions changed more in the midlittoral than in the infralittoral zone and created a less stable habitat favourable to the preferential development of one generation over the other. The population at Porz Liogan was also different from that of New Hampshire (Mathieson \& Burns 1975) in that, except at the beginning of winter and middle of fall, tetrasporophytes were less abundant than gametophytes whatever the level on the shore. They were, however, twice as frequent in the infralittoral than in the midlittoral zone, which corroborates the observations of Mathieson \& Burns (1975) and Craigie \& Pringle (1978). When gametophytes and tetrasporophytes were considered together, the 2 forms showed a different reproductive phenology as mature plants represented $29.2 \%$ in the infralittoral form and $20.8 \%$ in the midlittoral form.

The generally observed greater size of the adult plants of the infralittoral form over those of the midlittoral form could be explained by the difference in growth rate, both transverse and longitudinal, between the 2 forms, as displayed by fluorescence labelling. The growth of Chondrus crispus has been studied in different locations on both sides of the Atlantic Ocean (Chopin 1986); generally, it is significant during spring, maximal in summer, and minimal during winter. In Britanny, it was maximal during fall. Causes of shifts in the optima seem to be essentially related to the environmental conditions particular to each study site and to the units chosen to measure the growth (length, surface, biomass, number of newly formed rows of cortical cells). 
Contents of total carrageenans were comparable in the 2 forms. There was only a trend for the infralittoral form to have a higher content in summer and a lower content at the end of winter and the beginning of spring. The most-quoted biological roles of the cell-wall polysaccharides of algae are mechanical, hydration, and electro-chemical regulation (Rees 1962, Kloareg \& Quatrano 1988). A role in hydration regulation has been promoted by authors who established a positive correlation between the vertical distribution on the shore of the Phaeophyceae and their cell-wall thickness or content (Black 1954, Zaneveld 1969, de Lestang-Laisne \& Quillet 1972). Other authors, however, indicated no correlation between thallus water retention, thickness of cell walls and shore location (Dromgoole 1980, Schönbeck \& Norton 1980, Norton et al. 1982). Nevertheless, resistance to desiccation is closely related to bathymetric level and appears to depend on physiological mechanisms preventing dehydration. These involve not only internal metabolic adaptations (Kremer \& Schmitz 1973, Quadir et al. 1979) but also the buffer capacity of the cell wall at the cellular level and the osmotic pressure regulation by gel elasticity of the matrix compounds at the plasmalemma level (Kloareg \& Quatrano 1988). The hydration regulating role of carrageenans in Rhodophyceae is, however, questionable. Fuller \& Mathieson (1972), and Mathieson \& Tveter (1975) showed that carrageenan content of Chondrus crispus was lower in midlittoral than in infralittoral plants in New Hampshire. In Britanny, as the seasonal pattern of carrageenan content was not statistically different between the 2 forms, which are partly identified by their location on the shore, no correlation between vertical distribution and carrageenan content could be established.

The contrasting morphologies of these 2 forms could not be explained by cell-wall differences, either at the total carrageenan content level or at the level of the carrageenan structures, which were remarkably stable both qualitatively (the $k-, l-$, and $\mu$-structures occurred all year in both forms) and quantitatively (the slight variations in $\kappa$ - and $\mu$-structures were at the threshold of significance using the ${ }^{13} \mathrm{C}-\mathrm{NMR}$ technique).

Concerning $P$ nutrition, seasonal variations of total $P$ content were more pronounced, and the spring decline started 1 mo earlier, in the midlittoral than in the infralittoral form. The lower total $P$ content in the infralittoral form could be explained by its higher growth rate and consequently greater dilution of $P$ in growing tissues. The seasonal variations of $P$ content in seawater have a greater range than those in the thallus (Chopin et al. 1990b). These variations governed, at least partially, seasonal variations in the concentration factor, which however had an inverse pattern (highest values during late spring and summer). Moreover, as the total P content was higher, except at the end of
May, in the midlittoral than in the infralittoral form, the concentration factor was always higher in the former, especially during summer. Such high values for the $P$ concentration factor are comparable to those recorded in other algae such as Laminaria hyperborea (Floc'h 1982). They cannot be explained by simple passive ionic exchanges but only by active metabolic absorption (Chopin 1985).

The seasonal variations of total $\mathrm{N}$ content in this study are similar to those reported in other studies for Chondrus crispus (Mathieson \& Tveter 1975, Kornfeldt 1982) and other red algae (Lapointe \& Ryther 1979, Rosenberg \& Ramus 1982, Bird 1984), brown algae (Chapman \& Craigie 1977. Gagné et al. 1982), and green algae (Hanisak 1979, Birch et al. 1981, Gordon et al. 1981). Seasonal variations of irradiance could be one of the main factors responsible for those of $\mathrm{N}$ content (Lapointe \& Tenore 1981, Morgan \& Simpson 1981, Kornfeldt 1982). According to Durako \& Dawes (1980), high irradiance and temperature during summer induce protein degradation and bleaching of red algae which then turn greenish. The latter phenomenon is well known in $C$. crispus (Chopin 1986) and affected the infralittoral more than the midlittoral form (unpubl. data). This was confirmed by the different pattern of total $N$ content from June to August in the 2 forms: increase in the midlittoral form and decrease in the infralittoral one. Mathieson \& Tveter (1975), who also observed this difference between the 2 forms during summer, attributed it to the midlittoral plants having a broader tolerance to environmental factors compared to the infralittoral ones. Another explanation could be an interaction between $\mathrm{P}$ and $N$ nutrition. Lapointe $(1985,1987)$ suggested that severe $\mathrm{P}$ limitation can induce $\mathrm{N}$ limitation in Gracilaria tikvahiae. In our case, the total $\mathrm{P}$ content of the infralittoral form in August reached $0.15 \%$ (dry wt), which is in the range of the critical $\mathrm{P}$ content for growth as defined for other red and brown algae (Manley \& North 1984, Lapointe 1985, Chopin et al. 1990a), $N$ depletion continued and bleaching occurred. In the midlittoral form, the total P content in August was barely below $0.2 \%$ dry wt, which is the upper limit of the critical $P$ content for growth, while, instead of decreasing, total $N$ content increased to the March level and bleaching was not as severe as in the infralittoral form

Vertical location on the shore had a statistically significant influence on the dry matter content, the infralittoral form having a lower content than the midlittoral form all year long. Summer and winter maxima of dry matter content have also been reported for other algae (Wort 1955); however, these results partially disagreed with those of Vinogradov (1953), who found dry matter content of cold and temperate Rhodophyceae to be also high during summer and fall but low during winter. These differences in periods of maximal or minimal dry 
matter content seem due to geographical variations, as indicated by Morgan et al. (1980) in Palmaria palmata and by Munda (1972) in several algae including Chondrus crispus. Neish et al. (1977) showed that nutrient enrichment of seawater led to a decrease of dry matter content of $C$. crispus in culture. This is not corroborated by our results in which levels of dry matter were high in winter, a period of high nutrient concentration in seawater in Brittany (Chopin et al. 1990b).

This study has demonstrated differences (at the level of the distribution of mature female gametophytes and tetrasporophytes, growth, phosphorus and nitrogen nutrition, and dry matter content) and similarities (at the level of the carrageenans) in the eco-physiology and biochemistry of these 2 most contrasting forms of Chondrus crispus. However they do not allow the question of their significance to be settled. Are they the reflection of environmental variations relative to their location on the shore or the expression of the genetic component of the polymorphism of this species? To test the first hypothesis, studies similar to the present one should be conducted on algae with as extended a vertical distribution as $C$. crispus but without presenting polymorphitic plants (gametophytes of Mastocarpus stellatus, for example). For the second hypothesis, it would be desirable to conduct studies of transplants, tissue cultures, formation of reproductive organs, structure, and hybridization, in a more thorough fashion than previously (Floc'h 1969, Chen \& Taylor 1978, 1980a, b, Guiry 1979), to be able to define the degree of speciation represented by the presently observed polymorphism in what is today designated as the single entity C. crispus. The short duration of previous studies (between 5 and $13 \mathrm{mo}$ ), the fact that they were conducted on plants that already had well-channeled morphogenetic potentialities, and the questionable choice of the parental stocks should prompt one to be cautious in reaching any conclusion. Guiry (1991) showed interfertility between different populations of $C$. crispus with different morphologies, and between different species of the genus Chondrus, emphasizing that in the plant kingdom crossability is not an absolute criterion of speciation. Analyses of enzymatic systems by electrophoresis, already initiated by Cheney \& Mathieson (1979), and DNA/RNA sequencing techniques should provide new insights on the presence, or absence, of genetic divergence between the 2 forms, and, therefore, on their level of speciation.

Acknowledgements. This work was supported by a grant from the Direction Générale de la Recherche Scientifique et Technique of France and by a NSERC Operating Grant OGP46376 to T Chopin. We thank E. Guittet and J.-Y. Lallemand, Institut de Chimie des Substances Naturelles, CNRS, for the ${ }^{13} \mathrm{C}$-NMR spectra and discussion. The help of $J$. Farrah and $\mathrm{P}$. Hayes in preparing the manuscript is also appreciated.

\section{LITERATURE CITED}

Bellion, C., Brigand, G., Prome, J. C., Welti, D., Bociek, S. (1983). Identification et caractérisation des précurseurs biologiques des carraghénanes par spectroscopie de R.M.N. ${ }^{13}$ C. Carbohydr. Res. 119: 31-48

Bhattacharya, D. (1985). The demography of fronds of Chondrus crispus Stackhouse. J. exp. mar Biol. Ecol. 91 217-231

Birch, P. B., Gordon, D. M., McComb, A. J. (1981). Nitrogen and phosphorus nutrition of Cladophora in the Peel-Harvey estuarine system, Western Australia. Bot. Mar. 24: $381-387$

Bird, K. T. (1984). Seasonal variation in protein: carbohydrate ratios in a subtropical estuarine alga, Gracilaria verrucosa, and the determination of nitrogen limitation status using these ratios. Bot. Mar. 27: 111-115

Black, W. A. P. (1954). The seasonal variation in the combined L-fucose content of the common British Laminariaceae and Fucaceae. J. Sci. Food Agric. 5: 445-448.

Chapman, A. R. O., Craigie, J. S. (1977). Seasonal growth in Laminaria longicruris: relations with dissolved inorganic nutrients and internal reserves of nitrogen. Mar. Biol. 40 $197-205$

Charlot, G. (1966). Les méthodes de la chimie analytique Analyse quantitative minérale, 5th edn. Masson, Paris

Chen, L. C.-M., Taylor, A. R. A. (1978). Medullary tissue culture of the red alga Chondrus crispus. Can. J. Bot. 56: 883-886

Chen, L. C.-M., Taylor, A. R. A. (1980a). Investigations of distinct strains of Chondrus crispus Stackh. I. Field and laboratory observations. Bot. Mar. 23: 435-440

Chen, L. C.-M., Taylor, A. R. A. (1980b). Investigations of distinct strains of Chondrus crispus Stackh. II. Culture studies. Bot. Mar 23: 441-448

Cheney, D. P., Mathieson, A. C. (1979). Population differentiation in the seaweed Chondrus crispus: preliminary results. Insozyme Bull. 12: 57

Chopin, T. (1985). Variations saisonnières de la nutrition phosphorée, des carraghénanes et de la croissance chez deux formes de l'algue rouge Chondrus crispus Stackhouse. Thèse de doctorat de 3ème cycle, Université de Brest, France

Chopin, T (1986). The red alga Chondrus crispus Stackhouse (Irish moss) and carrageenans - a review. Can. Tech. Rep. Fish. Aquat. Sci. 1514: V +69

Chopin, T., Bodeau-Bellion, C., Floc'h, J.-Y., Guittet, E., Lallemand, J.-Y (1987). Seasonal study of carrageenan structures from female gametophytes of Chondrus crispus Stackhouse (Rhodophyta). Hydrobiologia 151/152: $535-539$

Chopin, T., Floc'h, J.-Y (1987). Seasonal variations of growth in the red alga Chondrus crispus on the Atlantic French coasts. I. A new approach by fluorescence labelling. Can. J. Bot. $65 ; 1014-1018$

Chopin, T., Hanisak, M. D., Koehn, F. E., Mollion, J., Moreau, S. (1990a). Studies on carrageenans and effects of seawater phosphorus concentration on carrageenan content and growth of Agardhiella subulata (C. Agardh) Kraft and Wynne (Rhodophyceae, Solieriaceae). J. appl. Phycol. 2: 3-16

Chopin, T., Hourmant, A., Floc'h, J.-Y., Penot, M. (1990b). Seasonal variations of growth in the red alga Chondrus crispus on the Atlantic French coasts. II. Relations with phosphorus concentration in seawater and internal phosphorylated fractions. Can. J. Bot. 68: 512-517

Chopin, T., Pringle, J. D., Semple, R. E. (1988). Reproductive 
capacity of dragraked and non-dragraked Irish moss (Chondrus crispus Stackhouse) beds in the southern Gulf of St. Lawrence. Can. J. Fish. Aquat. Sci. 45: 758-766

Craigie, J. S., Leigh, C. (1978). Carrageenans and agars. In Hellebust, J. A., Craigie, J. S. (eds.) Handbook of phycological methods. Physiological and biochemical methods. Cambridge University Press, London, p. 109-131

Craigie, J. S., Pringle, J. D. (1978). Spatial distribution of tetrasporophytes and gametophytes in four maritime populations of Chondrus crispus. Can. J. Bot. 56 2910-2914

de Lestang-Laisne, G., Quillet, M. (1972). Sur la fucoidine des algues brunes. Bull. Lab. mar. Dinard 1: 217-224

Dromgoole, F. I. (1980). Desiccation resistance of intertidal and subtidal algae. Bot. Mar. 23: 149-159

Durako, M. J., Dawes, C. J. (1980). A comparative seasonal study of two populations of Hypnea musciformis from the east and west coasts of Florida, USA. I. Growth and chemistry. Mar. Biol. 59: 151-156

Fernandez, C., Menendez, M. P. (1991). Ecology of Chondrus crispus Stackhouse on the northern coast of Spain. II. Reproduction. Bot. Mar. 34: 303-310

Floc'h, J.-Y. (1969). Premiers résultats d'une expérience de transplantation du Chondrus crispus (L. ) Lyngb. In: Margalef, R. (ed.) Proc. 6th Int. Seaweed Symp., Santiago de Compostela. Dirección General de Pesca Marítima, Madrid, p. 171-177

Floc'h, J.-Y (1982). Uptake of inorganic ions and their long distance transport in Fucales and Laminariales. In: Srivastava, L. M. (ed.) Synthetic and degradative processes in marine macrophytes. De Gruyter W. \& Co., Berlin, p. $139-166$

Fuller, S. W., Mathieson, A. C. (1972). Ecological studies of economic red algae. IV Variations of carrageenan concentration and properties in Chondrus crispus Stackhouse. J exp. mar. Biol. Ecol. 10: 49-58

Gagné, J. A., Mann, K. H., Chapman, A. R. O. (1982). Seasonal patterns of growth and storage in Laminaria longicruris in relation to differing patterns of availability of nitrogen in the water Mar. Biol. 69: 91-101

Gordon, D. M., Birch, P. B., McComb, A. J. (1981). Effects of inorganic phosphorus and nitrogen on the growth of an estuarine Cladophora in culture. Bot. Mar. 24: 93-106

Guiry, M. D. (1979). The life history in laboratory culture of an isolate of Chondrus crispus Stackh. (Rhodophyta) from Scotland. Br. Phycol. J. 14: 124

Guiry, M. D. (199l). Crossability data and the species concept in marine red algae. J. Phycol. 27 (suppl.): 27

Hanic, L. A. (1973). Cytology and genetics of Chondrus crispus Stackhouse In: Harvey, M. J., McLachlan, J. (eds.) Chondrus crispus. Proc. N. S. Inst. Sci., Halifax, 27 (suppl.) p. 23-52

Hanisak, M. D. (1979) Growth patterns of Codium fragile ssp tomentosoides in response to temperature, irradiance, salinity and nitrogen source. Mar Biol. 50: 319-332

Harvey, W. H. (1846-185l). Phycologia britannica. Vol. III Reeve and Co., London

Hourmant, A., Pradet, A., Penot, M. (1979). Action de la benzylaminopurine sur l'absorption du phosphate et le métabolisme des composés phosphorylés des disques du tubercule de Pomme de terre en survie. Physiol. vég. 17: 483-499

Kloareg, B., Quatrano, R. S. (1988). Structure of the cell walls of marine algae and ecophysiological functions of the matrix polysaccharides. Oceanogr. mar. Biol. Ann. Rev. 26: 259-315

Kornfeldt, R.-A. (1982). Relation between nitrogen and phos- phorus content of macroalgae and the waters of northern Öresund. Bot. Mar. 25: 197-201

Kremer, B. P., Schmitz, K. (1973). CO $\mathrm{CO}_{2}$-Fixierung und Stofftransport in benthischen marinen Algen. IV Zur ${ }^{14} \mathrm{C}$ Assimilation einiger litoraler Braunalgen in submersen und emersen Zustand. Z. PflPhysiol. 68: 357-363

Lamouroux, J. V (1805). Dissertations sur plusieurs espèces de Fucus, peu connues ou nouvelles, avec leur description en latin et en français. Noubel, Agen

Lamouroux, J. V (1813). Essai sur les genres de la famille des Thalassiophytes non articulées. Ann. Mus. Hist. Nat. Paris $20: 21-47,115-139,267-293$

Lapointe, B. E. (1985). Strategies for pulsed nutrient supply to Gracilaria cultures in the Florida Keys: interactions between concentration and frequency of nutrient pulses. J. exp. mar. Biol. Ecol. 93: 211-222

Lapointe, B. E. (1987). Phosphorus- and nitrogen-limited photosynthesis and growth of Gracilaria tikvahiae (Rhodophyceae) in the Florida Keys: an experimental field study. Mar. Biol. 93: 561-568

Lapointe, B. E., Ryther, J. H. (1979). The effects of nitrogen and seawater flow rate on the growth and biochemical composition of Gracilaria foliffera var angustissima in mass outdoor cultures. Bot. Mar 22: 529-537

Lapointe, B. E., Tenore, K. R. (1981). Experimental outdoor studies with UIva fasciata Delile. I. Interaction of light and nitrogen on nutrient uptake, growth and biochemical composition. J. exp. mar Biol. Ecol. 53: 135-152

Lazo, M. L., Greenwell, M., McLachlan, J. (1989). Population structure of Chondrus crispus Stackhouse (Gigartinaceae, Rhodophyta) along the coast of Prince Edward Island, Canada: distribution of gametophytic and sporophytic fronds. J. exp. mar. Biol. Ecol. 126: 45-58

Lilly, G. R. (1968). Some aspects of the ecology of Irish moss, Chondrus crispus (L.) Stack., in Newfoundland waters. Fish. Res. Bd Can., Tech. Rep. 43: 1-44

MacFarlane, C. I. (1956). Irish moss in the Maritime Provinces. Nova Scotia Res. Found, Halifax, Nova Scotia, p. 1-20

MacFarlane, C. I. (1968). Chondrus crispus Stackhouse - a synopsis. Nova Scotia Res. Found., Seaweeds Div, Halifax, Nova Scotia, p. $1-48$

Manley, S. L., North, W. J. (1984). Phosphorus and the growth of juvenile Macrocystis pyrifera (Phaeophyta) sporophytes. J. Phycol. 20: 389-393

Mathieson, A. C., Burns, R. L. (1975). Ecological studies of economic red algae. V. Growth and reproduction of natural and harvested populations of Chondrus crispus Stackhouse in New Hampshire. J. exp. mar Biol. Ecol. 17: 137-156

Mathieson, A. C., Tveter, E. (1975). Carrageenan ecology of Chondrus crispus Stackhouse. Aquat. Bot. 1. 25-43

Morgan, K. C., Simpson, F. J. (1981). The cultivation of Palmaria palmata. Effect of light intensity and nitrate supply on growth and chemical composition. Bot. Mar. 24: $273-277$

Morgan, K. C., Wright, J. L. C., Simpson, F. J. (1980). Review of chemical constituents of the red alga Palmaria palmata (Dulse). Econ. Bot. 34: 27-50

Munda, I. (1972). On the chemical composition, distribution and ecology of some common benthic marine algae from Iceland. Bot. Mar. 15: 1-45

Neish, A. C., Fox, C. H. (1971). Greenhouse experiments on the vegetative propagation of Chondrus crispus (Irish moss). NRCC, ARL Tech. Rep. 12: 1-68

Neish, A. C., Shacklock, P. F., Fox, C. H., Simpson, F. J. (1977). The cultivation of Chondrus crispus. Factors affecting growth under greenhouse conditions. Can. J. Bot. 55: $2263-2271$ 
Newton, L., Devonald, V. G., Jones, N. R. (1957). Recherches sur Chondrus crispus (L. ) Stackh, et quelques unes de ses soi-disant variétés. In: $81^{e}$ Colloque Int. CNRS, Ecologie des algues marines, Dinard. CNRS, Paris, p. 121-139

Norton, T A., Mathieson, A. C., Neushul, M. (1982). A review of some aspects of form and function in seaweeds. Bot. Mar. 25: 501-510

Prince, J. S. (1971). An ecological study of the marine red alga Chondrus crispus in the waters off Plymouth, Massachusetts. Ph.D. thesis, Cornell University, Ithaca

Prince, J. S., Kingsbury, J. M. (1973). The ecology of Chondrus crispus at Plymouth Massachusetts. II. Field studies. Am. J. Bot. 60: 964-975

Quadir, A., Harrison, P. J., de Wreede, R. E. (1979). The effects of emergence and submergence on the photosynthesis and respiration of marine macrophytes. Phycologia 18: 83-88

Rees, D. A. (1962). Some properties of the cell wall mucilage of marine algae. Br. Phycol. Bull. 2: 180-181

Rosenberg, G., Ramus, J. (1982). Ecological growth strategies in the seaweeds Gracilaria folifera (Rhodophyceae) and Ulva sp. (Chlorophyceae): soluble nitrogen and reserve carbohydrates. Mar. Biol. 66: 251-259

Schönbeck, M. W. Norton, T. A. (1980). The effects on intertidal fucoid algae of exposure to air under various conditions. Bot. Mar. 23: 141-147

This article was submitted to the editor
Stackhouse, J. (1809). Tentamen Marino-cryptogamicum. Mém. Soc. Imp. Nat, Moscow 2: 50-97

Stancioff, D. J., Stanley, N. F. (1969). Infrared and chemical studies on algal polysaccharides. In: Margalef, $R$. (ed.) Proc. 6th Int. Seaweed Symp., Santiago de Compostela. Dirección General de Pesca Marítima, Madrid, p. 595-609

Thomas, M. (1938). Der Formenkreis von Chondrus crispus und seine okologische Bedingtheit. Hedwigia 77: 137-210

Tveter-Gallagher, E., Mathieson, A. C., Cheney, D. P. (1980). Ecology and developmental morphology of male plants of Chondrus crispus (Gigartinales, Rhodophyta). J. Phycol. 16: $257-264$

Usov, A. I. (1984). NMR spectroscopy of red seaweed polysaccharides: agars, carrageenans, and xylans. Bot. Mar. 27 : 189-202

Vinogradov, A. P. (1953). The elementary chemical composition of marine organisms. Memoir 2, Sears Fd Mar. Res. Yale University, New Haven

Wort, D. J. (1955). The seasonal variation in chemical composition of Macrocystis integrifolia and Nereocystis luetkeana in British Columbia coastal waters. Can. J. Bot. 33: 323-340

Zaneveld, J. S. (1969). Factors controlling the delimitation of littoral benthic marine algal zonation. Am. Zool. 9: $367-391$

Manuscript first received: November 29, 1991

Revised version accepted: February 14, 1992 